\title{
Thermally-Gated Liposomes
}

\author{
Wen-Hua Chen and Steven L. Regen* \\ Department of Chemistry, Lehigh University, Bethlehem, Pennsylvania
}

18015

Supporting Information

\section{Synthesis of conjugates 1 and 2}

Conjugate 1

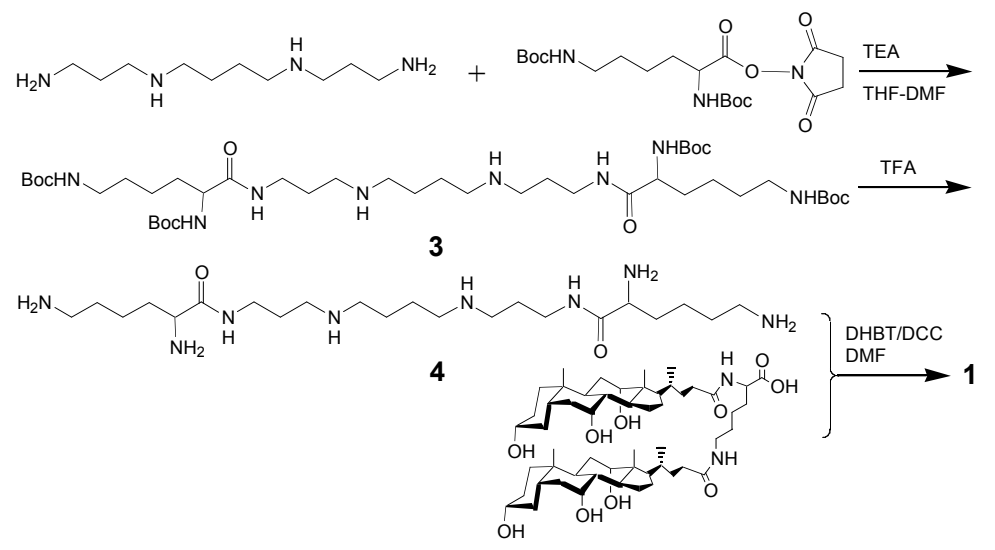

Compound 3. To a solution of spermine $(61 \mathrm{mg}, 0.30 \mathrm{mmol})$ and triethylamine $(0.28$ $\mathrm{mL})$ in $2.0 \mathrm{~mL}$ of anhydrous DMF-THF $(1 / 1, \mathrm{v} / \mathrm{v} /)$ was added $\mathrm{N}_{\alpha} \mathrm{N}_{\varepsilon}$-di-Boc- $L$-lysine hydroxylsuccinimide ester (Boc-(L)Lys(Boc)-Osu) $(280 \mathrm{mg}, 0.63 \mathrm{mmol})$. The slightly turbid reaction mixture was stirred at room temperature for $24 \mathrm{~h}$, and then concentrated under reduced pressure. Purification was achieved by chromatography using a silica-gel column, eluting with $\mathrm{CHCl}_{3} / \mathrm{MeOH} / \mathrm{NH}_{3} \cdot \mathrm{H}_{2} \mathrm{O}(50 / 10 / 1$, v/v/v) to give $143 \mathrm{mg}(55 \%)$ of 3 
having $R_{f} 0.46$ [silica, $\mathrm{CHCl}_{3} / \mathrm{MeOH} / \mathrm{NH}_{3} \cdot \mathrm{H}_{2} \mathrm{O}(50 / 10 / 1, \mathrm{v} / \mathrm{v} / \mathrm{v})$ ] and ${ }^{1} \mathrm{H} \mathrm{NMR}(500 \mathrm{MHz}$, $\left.\mathrm{CD}_{3} \mathrm{OD}, 298 \mathrm{~K}\right) \delta: 3.92$ (unresolved, $\left.2 \mathrm{H}\right), 3.34-3.22(8 \mathrm{H}$, overlapped with the signals from deuterium methanol), 2.62-2.59 (m, $8 \mathrm{H}), 1.71-1.31$ (m, $58 \mathrm{H})$. MALDI-TOF MS: $m / z 860\left([\mathrm{M}+\mathrm{H}]^{+}\right)$.

Compound 4. A solution of $3(50 \mathrm{mg}, 0.058 \mathrm{mmol})$ in trifluoroacetic acid $(2 \mathrm{~mL})$ was stirred at room temperature for $1 \mathrm{~h}$, and then concentrated under reduced pressure. The residue was then dried under vacuum for $4 \mathrm{~h}$ and used directly in the following reaction without further purification. The complete removal of Boc groups was confirmed by ${ }^{1} \mathrm{H}$ NMR (500 MHz, CD $\left.{ }_{3} \mathrm{OD}, 298 \mathrm{~K}\right) \delta: 3.86\left(\mathrm{t},{ }^{3} J=6.73\right.$ and $\left.6.65 \mathrm{~Hz}, 1 \mathrm{H}\right), 3.42(\mathrm{~m}, 2 \mathrm{H})$, 3.27-3.25 (m, $2 \mathrm{H}), 3.04\left(\mathrm{t},{ }^{3} J=7.48\right.$ and $\left.7.48 \mathrm{~Hz}, 8 \mathrm{H}\right), 2.93\left(\mathrm{t},{ }^{3} J=7.63\right.$ and $7.84 \mathrm{~Hz}, 4$ H), 1.98-1.76 (m, 12 H), 1.73-1.67 (m, 4 H), 1.52-1.42 (m, 4 H).

Compound 1. To a solution of lysine-dicholamide ${ }^{1}(405 \mathrm{mg}, 0.41 \mathrm{mmol})$ and 3-hydroxy1,2,3-benzotriazine-4(3H)-one (DHBT) $(90 \mathrm{mg}, 0.55 \mathrm{mmol})$ in anhydrous DMF (2 mL) was added DCC (115 mg, $0.56 \mathrm{mmol})$. After the mixture was stirred for $3 \mathrm{~h}$, a solution of 4 [prepared from $50 \mathrm{mg}$ of $\mathbf{3}$ and triethylamine $(500 \mu \mathrm{L})$ in anhydrous DMF $(1 \mathrm{~mL})$ ] was directly added. The resulting mixture was stirred for $24 \mathrm{~h}$, and then poured into $1 \mathrm{M}$ hydrochloride acid $(100 \mathrm{~mL})$. The resulting precipitate was collected by filtration and purified twice by chromatography on a silica gel column, eluting with $\mathrm{CHCl}_{3} / \mathrm{CH}_{3} \mathrm{OH} / \mathrm{H}_{2} \mathrm{O}(40 / 10 / 1, \mathrm{v} / \mathrm{v} / \mathrm{v})$ to give 1 (145 mg, 42\%) having $R_{f} 0.61$ [silica, $\left.\mathrm{CHCl}_{3} / \mathrm{CH}_{3} \mathrm{OH} / \mathrm{H}_{2} \mathrm{O}(40 / 10 / 1, \mathrm{v} / \mathrm{v} / \mathrm{v})\right]$ and ${ }^{1} \mathrm{H}$ NMR $\left(500 \mathrm{MHz}, \mathrm{CD}_{3} \mathrm{OD}, 323 \mathrm{~K}\right) \delta: 4.78$ (unresolved, $2 \mathrm{H}), 4.29$ (unresolved, $6 \mathrm{H}), 3.94$ (s, $12 \mathrm{H}), 3.80$ (s, $12 \mathrm{H}), 3.37-3.29(20 \mathrm{H}$, overlapped with the signals from deuterium methanol), 3.16 (m, $20 \mathrm{H}), 2.29-0.91$ (m, 416 H), 0.70 (s, $36 \mathrm{H})$. MALDI-TOF MS: $m / z 5937\left([\mathrm{M}+\mathrm{Na}]^{+}\right)$. 
Conjugate 2

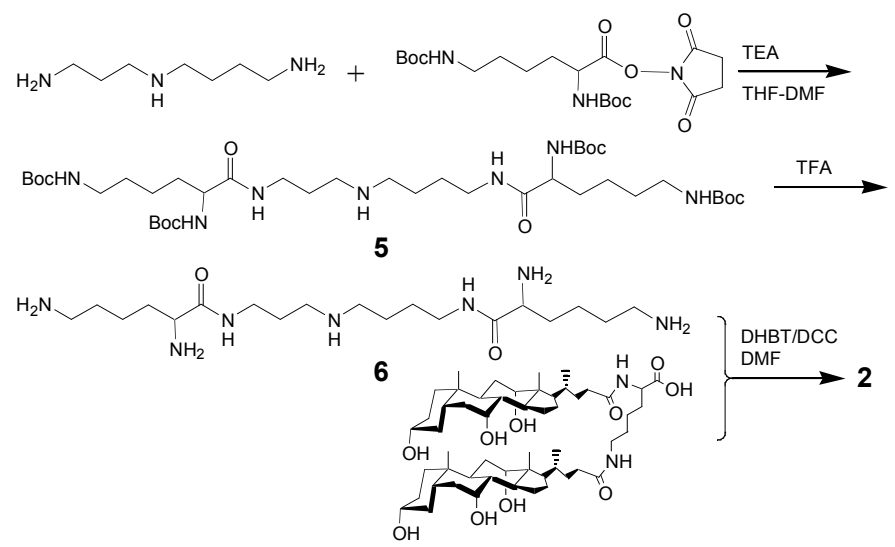

Compound 5. To a solution of spermidine $(94 \mathrm{mg}, 0.65 \mathrm{mmol})$ and triethylamine $(0.55$ $\mathrm{mL})$ in anhydrous DMF-THF (4 mL, 1/1, v/v) was added Boc- $(L) L y s(B o c)-O S u(620 \mathrm{mg}$, $1.40 \mathrm{mmol}$ ). The resulting turbid reaction mixture became transparent as the reaction proceeded. After stirring at room temperature for $24 \mathrm{~h}$, the solvents were removed under reduced pressure. Purification was achieved by chromatography on a silica-gel column, eluted with $\mathrm{CHCl}_{3} / \mathrm{MeOH} / \mathrm{NH}_{3} \cdot \mathrm{H}_{2} \mathrm{O}\left(75 / 10 / 1\right.$, v/v/v) to afford 5 (495 mg, 95\%) having $R_{f}$ 0.69 [silica, $\mathrm{CHCl}_{3} / \mathrm{MeOH} / \mathrm{NH}_{3} \cdot \mathrm{H}_{2} \mathrm{O}(75 / 10 / 1, \mathrm{v} / \mathrm{v} / \mathrm{v})$ ] and ${ }^{1} \mathrm{H} \mathrm{NMR}\left(500 \mathrm{MHz}, \mathrm{CDCl}_{3}\right.$, 298 K) ठ: 7.45 (br, 1 H), 7.11 (br, 1 H), 5.50 (br, 2 H), 4.89-4.83 (br, 2 H), 3.99 (m, 2 H), 3.27-3.01 (m, 8 H), 2.62-2.54 (m, 4 H), 1.71-1.29 (m, 54 H). MALDI-TOF MS: m/z 803 $\left([\mathrm{M}+\mathrm{H}]^{+}\right)$.

Compound 6. A solution of $5(52 \mathrm{mg}, 0.065 \mathrm{mmol})$ and trifluoroacetic acid $(1 \mathrm{~mL})$ in $\mathrm{CHCl}_{3}(1 \mathrm{~mL})$ was stirred at room temperature for $2 \mathrm{~h}$ and then concentrated under reduced pressure. The residue was then dried under vacuum for $4 \mathrm{~h}$ and used directly in the following reaction without further purification. The complete removal of Boc groups was confirmed by ${ }^{1} \mathrm{H}$ NMR (500 MHz, $\left.\mathrm{CD}_{3} \mathrm{OD}, 298 \mathrm{~K}\right) \delta: 3.86\left(\mathrm{t},{ }^{3} \mathrm{~J}=6.71\right.$ and $7.15 \mathrm{~Hz}$, $1 \mathrm{H}), 3.83\left(\mathrm{t},{ }^{3} J=6.61\right.$ and $\left.7.47 \mathrm{~Hz}, 1 \mathrm{H}\right), 3.42(\mathrm{~m}, 1 \mathrm{H}), 3.34-3.20(\mathrm{~m}, 4 \mathrm{H}$, overlapped 
with the signals of deuterium methanol), 3.05-3.00 (m, $4 \mathrm{H}), 2.92\left(\mathrm{t},{ }^{3} J=7.37\right.$ and 6.39 Hz, 4 H), 1.97-1.79 (m, 6 H), 1.76-1.58 (m, 8 H), 1.51-1.42 (m, 4 H).

Compound 2. To a solution of lysine-dicholamide (376 mg, $0.41 \mathrm{mmol}$ ) and DHBT (83 $\mathrm{mg}, 0.55 \mathrm{mmol})$ in anhydrous DMF $(3 \mathrm{~mL})$ was added DCC (107 $\mathrm{mg}, 0.55 \mathrm{mmol})$. After the mixture was stirred at room temperature for $3 \mathrm{~h}$, a solution of 6 [prepared from $52 \mathrm{mg}$ of 5 and triethylamine $(600 \mu \mathrm{L})$ in anhydrous DMF $(1 \mathrm{~mL})]$ was directly added. The reaction mixture was stirred at room temperature for $24 \mathrm{~h}$ and then poured into $1 \mathrm{M}$ hydrochloride acid $(100 \mathrm{~mL})$. The resulting precipitate was collected by filtration and purified twice by chromatography on a silica-gel column, eluted with $\mathrm{CHCl}_{3} / \mathrm{CH}_{3} \mathrm{OH} / \mathrm{H}_{2} \mathrm{O}(40 / 10 / 1, \mathrm{v} / \mathrm{v} / \mathrm{v})$ to give $2(169 \mathrm{mg}, 53 \%)$ having $\mathrm{R}_{f} 0.65$ [silica, $\left.\mathrm{CHCl}_{3} / \mathrm{CH}_{3} \mathrm{OH} / \mathrm{H}_{2} \mathrm{O}(40 / 10 / 1, \mathrm{v} / \mathrm{v} / \mathrm{v})\right]$ and ${ }^{1} \mathrm{H}$ NMR $\left(500 \mathrm{MHz}, \mathrm{CD}_{3} \mathrm{OD}, 328 \mathrm{~K}\right) \_: 4.78$ (unresolved, $1 \mathrm{H}$ ), 4.29 (unresolved, $6 \mathrm{H}), 3.94$ (s, $10 \mathrm{H}), 3.80$ (s, $10 \mathrm{H}), 3.39-3.29$ (m, 14 $\mathrm{H}$, overlapped with the signals from deuterium methanol), 3.29-3.16 (m, $18 \mathrm{H}), 2.29-0.91$ (m, $348 \mathrm{H}), 0.70$ (s, $30 \mathrm{H})$. MALDI-TOF MS: $m / z 4971\left([\mathrm{M}+\mathrm{Na}]^{+}\right)$.

\section{POPC Vesicle Formation and $\mathrm{Na}^{+} / \mathrm{K}^{+}$Transport Measurements ${ }^{2}$}

Typically, $2.5 \mathrm{~mL}$ of a $20 \mathrm{mg} / \mathrm{mL}$ solution of 1-palmitoyl-2-oleoyl-2-sn-glycero-3phosphocholine (POPC) in chloroform was transferred to a Pyrex test tube. The desired amount of ion conductor was then added from a stock solution in methanol. While rotating the tube, the organic solvents were evaporated using a stream of nitrogen, resulting in a thin lipid film. The last traces of solvent were then removed under reduced pressure $\left(25^{\circ} \mathrm{C}, 12 \mathrm{~h},<0.2\right.$ Torr). To the dried film was added $1.0 \mathrm{~mL}$ of a $150 \mathrm{mM} \mathrm{KCl}$ solution that was $10 \%$ in $\mathrm{D}_{2} \mathrm{O}$ and $90 \%$ in $\mathrm{H}_{2} \mathrm{O}$, and the mixture vortexed for $1 \mathrm{~min}$. The dispersion was then incubated for $5 \mathrm{~min}$, followed by another $1 \mathrm{~min}$ of vortexing and 20 
min of incubation at ambient temperature. The sample was subjected to five freeze/thaw cycles $(77 \mathrm{~K} / 325 \mathrm{~K})$, followed by extrusion through a $400 \mathrm{~nm}$ Nuclepore membrane (10 times) and a $200 \mathrm{~nm}$ membrane (10 times). After extrusion, the dispersion was incubated for 1-2 $\mathrm{h}$ at room temperature. In a quartz NMR tube, $1.5 \mathrm{~mL}$ of a $150 \mathrm{mM} \mathrm{NaCl}$ solution in $10 \% \mathrm{D}_{2} \mathrm{O}$ plus $90 \% \mathrm{H}_{2} \mathrm{O}$ was mixed with $0.3 \mathrm{~mL}$ of a shift reagent solution $(10 \mathrm{mM}$ $\mathrm{DyCl}_{3} ; 30 \mathrm{mM} \mathrm{Na}_{5} \mathrm{P}_{3} \mathrm{O}_{10}$ in $10 \% \mathrm{D}_{2} \mathrm{O}$ plus $90 \% \mathrm{H}_{2} \mathrm{O}$ ). To this solution was added 0.75 $\mathrm{mL}$ of the vesicle dispersion, and the resulting mixture was vortexed for $30 \mathrm{~s}$. NMR spectra were recorded continuously at $35^{\circ} \mathrm{C}$ overnight on a Bruker AMX 360 NMR instrument. Pseudo first-order rate constants were calculated from the change in the percentage of encapsulated $\mathrm{Na}^{+}$as a function of time using a curve-fitting procedure.

\section{DPPC Vesicle Formation ${ }^{3}$ and Carboxyfluorescein Release Measurements}

Typically, $2.0 \mathrm{~mL}$ of a $25 \mathrm{mg} / \mathrm{mL}$ solution of 1-dipalmitoyl-sn-glycero-3-phosphocholine (DPPC) in chloroform was transferred to a Pyrex test tube. The desired amount of $\mathbf{1}$ was then added from a stock solution in methanol. While rotating the tube, the organic solvents were evaporated using a stream of nitrogen, resulting in a thin lipid film. The last traces of solvent were then removed under reduced pressure $\left(25^{\circ} \mathrm{C}, 18 \mathrm{~h}\right)$. To the dried film was added $1.0 \mathrm{~mL}$ of a $50 \mathrm{mM}$ carboxyfluorescein (CF) solution in $10 \mathrm{mM}$ HEPES buffer $(\mathrm{pH} 7.4)$ at $60^{\circ} \mathrm{C}$. The resulting mixture was vortexed for $15 \mathrm{~s}$, incubated at $60^{\circ} \mathrm{C}$ for $15 \mathrm{~s}$ and vortexed $15 \mathrm{~s}$. The dispersion was then incubated at $60^{\circ} \mathrm{C}$ for $5 \mathrm{~min}$, vortexed for $15 \mathrm{~s}$ twice and incubated at $60^{\circ} \mathrm{C}$ for another $20 \mathrm{~min}$. The sample was subjected to five freeze/thaw cycles $(77 \mathrm{~K} / 333 \mathrm{~K})$, followed by extrusion through a 400 $\mathrm{nm}$ Nuclepore membrane (10 times) and a $200 \mathrm{~nm}$ membrane $\left(10\right.$ times) at $60^{\circ} \mathrm{C}$. After extrusion, the dispersion was incubated at room temperature for $1.25 \mathrm{~h}$, the non- 
entrapped CF was removed via gel filtration (Sephadex G-25, 1x32 cm, eluting with 10 mM HEPES buffer ( $\mathrm{pH} 7.4)$ ). The vesicle dispersion $(0.2 \mathrm{~mL})$ was added to $1.8 \mathrm{~mL}$ of a $10 \mathrm{mM}$ HEPES buffer ( $\mathrm{pH}$ 7.4), which was maintained at the desired temperature on a Perkin Elmer Luminescence Spectrometer LS50B. The appearance of fluorescence intensity was then monitored as a function of time (ex $490 \mathrm{~nm}$, em $514 \mathrm{~nm}$, ex/em 2.5 $\mathrm{nm} / 2.5 \mathrm{~nm}$ ). After $60 \mathrm{~min}, 50 \mu \mathrm{L}$ of $5 \mathrm{wt} \%$ Triton X-100 in $10 \mathrm{mM}$ HEPES buffer (pH 7.4) was added. The amount of CF that was released from the vesicles was then calculated using the following equation: CF release $(\%)=\left(I-I_{0}\right) /\left(I_{\text {total }}-I_{0}\right) \times 100$, where $I_{0}, I$ and $I_{\text {total }}$ represent the fluorescence intensities of the dispersion at the initial time, after a period of time and after addition of $5 \mathrm{wt} \%$ aqueous solution of Triton X-100, respectively.

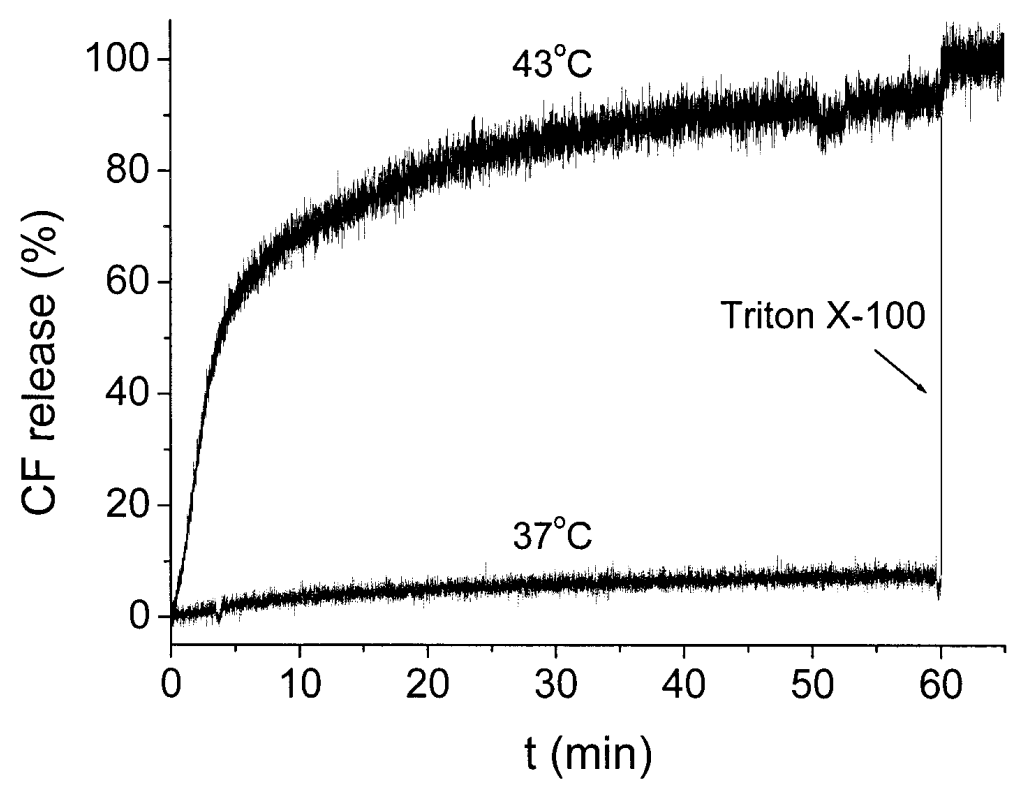

Figure S1. Plot of percentage of CF release from liposomes made from DPPC-DSPC $(9 / 1, \mathrm{wt} / \mathrm{wt})$ containing $0.01 \mathrm{~mol} \% \mathbf{1}$ as a function of time at $37^{\circ} \mathrm{C}$ and $43^{\circ} \mathrm{C}$. 


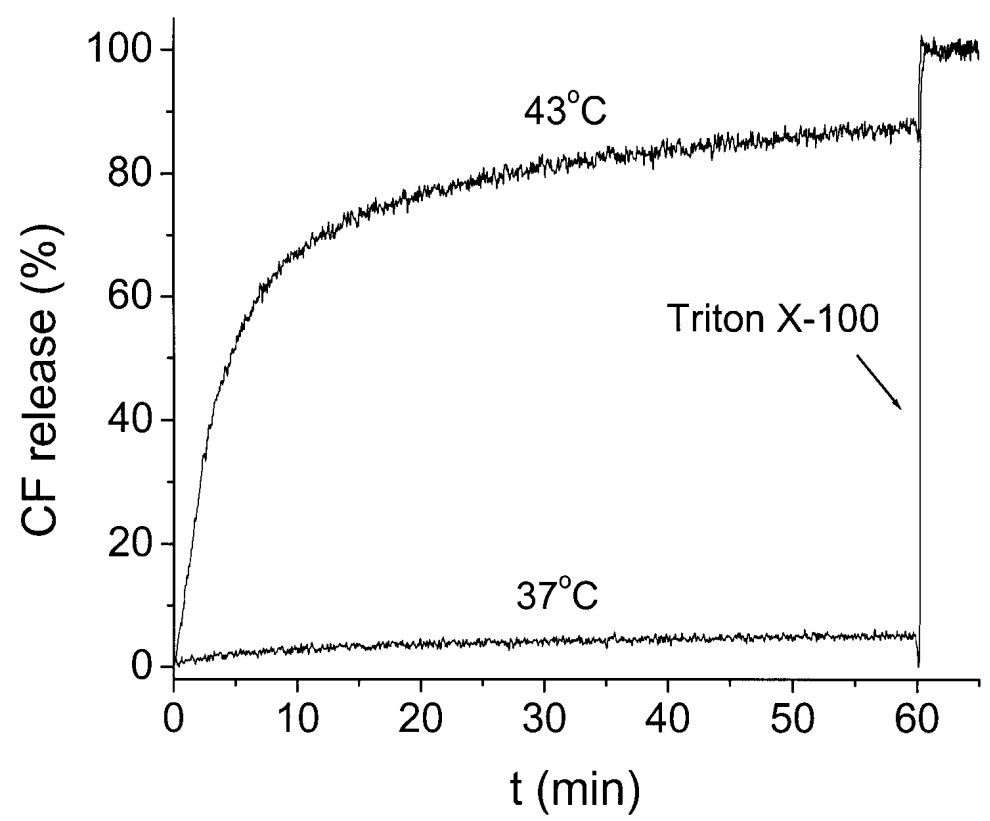

Figure S2. Plot of percentage of CF release from liposomes made from DPPC containing $0.01 \mathrm{~mol} \% 2$ as a function of time at $37^{\circ} \mathrm{C}$ and $43^{\circ} \mathrm{C}$.

\section{REFERENCES:}

1. Bandyopadhyay, P,; Bandyopadhyay, P.; Regen, S. L. Bioconjugate Chem., 2002, 13, 1314-1318.

2. Zhang, J.; Jing, B.; Regen, S. L J. Am. Chem. Soc., 2003, 125, 13984-13987.

3. Otto, S.; Osifchin, M.; Regen, S. L. J. Am. Chem. Soc., 1999, 121, 10440-10441. 

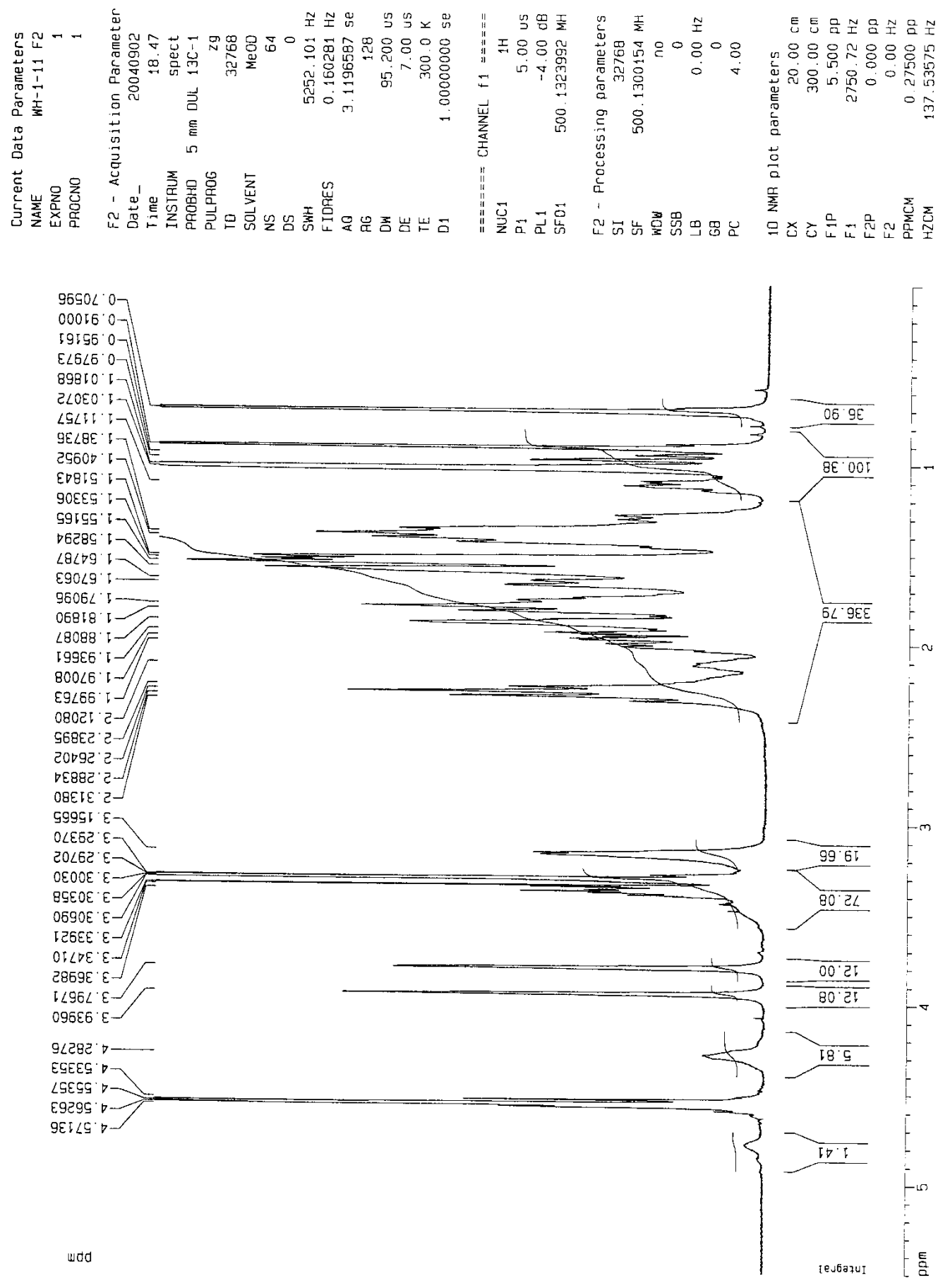

Figure S1. ${ }^{1} \mathrm{H}$ NMR spectrum $(500 \mathrm{MHz})$ of conjugate $\mathbf{1}$ in $\mathrm{CD}_{3} \mathrm{OD}$ at $323 \mathrm{~K}$. 

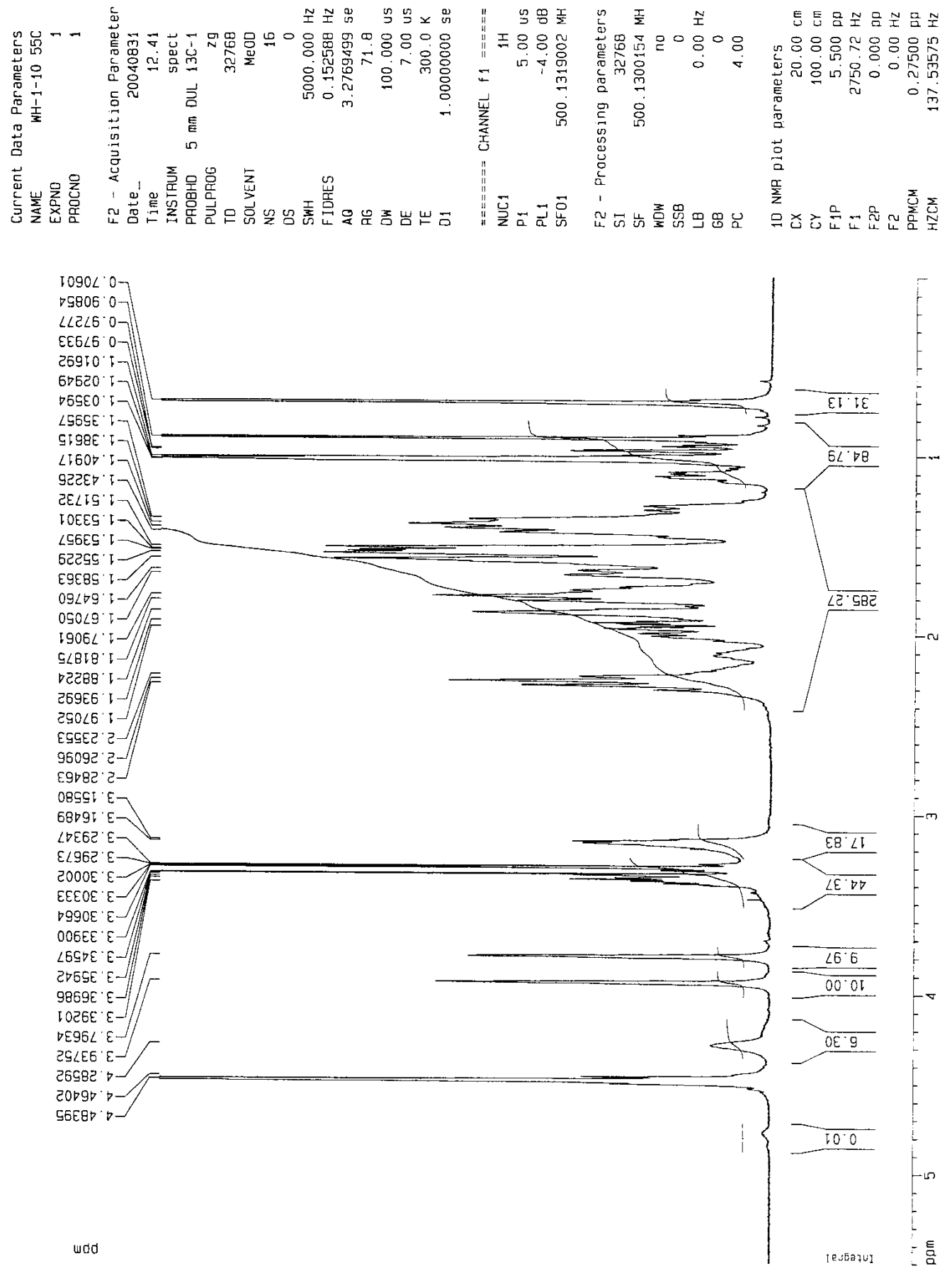

Figure S2. ${ }^{1} \mathrm{H}$ NMR spectrum $(500 \mathrm{MHz})$ of conjugate 2 in $\mathrm{CD}_{3} \mathrm{OD}$ at $328 \mathrm{~K}$. 